\title{
Investigation of the prevalence and clinical associations of antibodies to human fibronectin in systemic lupus erythematosus
}

\author{
M S Atta, K L Lim, D A Ala'Aldeen, R J Powell, I Todd
}

\begin{abstract}
Objectives-To assess the prevalence of antibodies to human fibronectin (anti-Fn) in sera of patients with certain connective tissue diseases and to determine their association with disease activity and the pattern of organ involvement in patients with systemic lupus erythematosus (SLE).

Methods-A capture enzyme linked immunosorbent assay (ELISA) was developed to quantify anti-Fn antibodies in serum samples from 65 patients with well characterised SLE, 50 with rheumatoid arthritis (RA), 15 with Behçet's disease (BD), 15 with systemic vasculitis and 36 healthy subjects. An anti-Fn antibody titre greater than mean + 3SD of the healthy control log values after back transformation to the normal scale was considered positive. Disease activity in SLE patients was scored using the British Isles Lupus Assessment Group (BILAG) Index. Erythrocyte sedimentation rate (ESR), concentrations of anti-dsDNA antibody, soluble interleukin-2 receptors (sIL-2R), C3, C4, C3 degradation products (C3dg) and immunoglobulin, and antinuclear antibody (ANA) titres were measured in blood samples from SLE patients; neopterin concentration was measured in corresponding urine samples.
\end{abstract}

Results-Anti-Fn antibodies were found in 22 of 65 SLE patients $(33.8 \%)$, seven of 50 with RA $(14 \%)$, one of 15 with $B D$ $(6.6 \%)$ and none of the 15 subjects with vasculitis. Thirty SLE patients had active disease and 35 had inactive disease; their median anti-Fn concentrations were 117 $\mathrm{u} / \mathrm{ml}$ (range 47-450) and $68 \mathrm{u} / \mathrm{ml}$ (range 17-334), respectively $(p=0 \cdot 0001)$. The presence of anti-Fn did not correlate with immunoglobulin concentrations or ANA titres in these sera. No significant difference was found between SLE patients with disease activity in one major organ system compared with multiple organ involvement, as defined by BILAG $(p=0 \cdot 19)$. However, patients with musculoskeletal manifestations had consistently greater anti-Fn concentrations compared with patients with other clinical manifestations. There were significant correlations between amounts of anti-Fn in SLE sera and ESR $\left(r_{\mathrm{s}}=0.25, p=0.045\right)$, sIL-2R $\left(r_{s}=0.28, p=0.024\right)$ and urine neopterin $\left(r_{s}=0.3, p=0.016\right)$ but not with serum anti-dsDNA antibody titres, plasma C3, C3dg or C4. However multiple regression analysis showed a low significant correlation only with SIL-2R and BILAG score $(p=0.047$ and 0.042 , respectively).

Conclusion-Anti-Fn antibodies were detected in $34 \%$ of SLE patients and in small proportions of $R A$ and $B D$ patients. An association between serum anti-Fn and disease activity in SLE has been identified and most SLE patients with musculoskeletal involvement had increased anti-Fn antibody concentrations.

(Ann Rheum Dis 1995; 54: 117-124)

Systemic lupus erythematosus (SLE) is a systemic autoimmune disease characterised by a range of antibodies reactive with a variety of self antigens, some of which are claimed to have clinical significance-for example antidouble stranded DNA (anti-ds DNA). ${ }^{1}$ Antibodies to fibronectin (anti-Fn) have been detected previously in sera from patients with SLE, rheumatoid arthritis (RA) and a case of morphoea. ${ }^{2-4}$ However, those assays used fibronectin from differing species as antigens and this may explain the varying prevalence reported $(28 \cdot 7-78 \%)$.

Fibronectin is a dimeric glycoprotein with different domains showing high affinity for collagen/gelatin, fibrin/fibrinogen, heparin, cell surface adhesion molecules, actin, and Staphylococcus aureus. It is found in two antigenically related forms: a soluble form in plasma and other body fluids, and an insoluble form on epithelial surfaces, in connective tissue matrices and associated with basement membranes. The soluble form opsonises denatured collagen coated particles, cytoskeletal debris, fibrin-fibrinogen complexes, connective tissue fragments and immune complexes. Cellular or insoluble Fn influences cell-cell interaction and cell adherence to collagenous substrata. ${ }^{5}$

In previous studies we have shown that antiFn antibodies from the sera of SLE patients preferentially bind to the collagen binding domain of $F n$ and can interfere with Fn-Fn, Fn-collagen and Fn-cell interactions. ${ }^{2} 6$ These effects have been demonstrated by the ability of these antibodies to reduce the deposition of Fn and collagen on in vitro cultured fibroblasts and to inhibit cell attachment to Fn coated surfaces. $^{6}$ A pathogenetic role for anti-Fn 
antibodies has also been indicated by animal studies in which immunisation with native and denatured $F n$ induced renal damage in mice and rabbits, ${ }^{78}$ and injection of anti-Fn into rats caused glomerular mesangial immune deposition. ${ }^{9}$ The clinical relevance of anti-Fn in human disease requires clarification.

We developed a capture enzyme linked immunosorbent assay (ELISA) to measure anti-human Fn antibody concentrations to assess their prevalence in certain connective tissue diseases and possible clinical relevance. In SLE, their association with patterns of organ involvement and disease activity was ascertained.

\section{Patients and methods}

PATIENTS

Sixty five patients fulfilling at least four of the 1982 revised American Rheumatology Association criteria ${ }^{10}$ for the classification of SLE were studied. There were 62 females and three males, with a mean age of 42.9 (SD 12.6) years. The computerised British Isles Lupus Assessment Group (BILAG) index of disease activity was used to assess lupus activity ${ }^{11}$ in the major organ systems (mucocutaneous, nervous, musculoskeletal, cardiovascular, vasculitis, renal, and haematological) and general constitutional manifestations. All the organ systems were graded A to E and BILAG scores of $9,3,1,0$ and 0 were considered to correspond grades $\mathrm{A}, \mathrm{B}, \mathrm{C}, \mathrm{D}$, and $\mathrm{E}$, respectively. Any system graded A or B was considered to display active disease. The overall BILAG score for an individual patient was the sum of the disease activity scores in the eight systems assessed.

The control groups consisted of 36 healthy subjects (mean age $42 \cdot 1$ (12) years; 34 females, two males), 50 patients with classical or definite RA (mean age $54.7(12 \cdot 2)$ years; 40 females, 10 males), 15 patients with systemic vasculitis (mean age 53 (14) years; nine females, six males), and 15 patients with Behçet's disease (mean age $38 \cdot 1$ (5) years, six females, nine males). None of the patients or controls had a concomitant bacterial or viral infection or other disorder at the time of investigation. All sera were stored at $-70^{\circ} \mathrm{C}$ until use.

POLYACRYLAMIDE GEL ELECTROPHORESIS (PAGE) AND SODIUM DODECYL SULPHATE PAGE (SDS-PAGE)

SDS-PAGE was performed in $7.5 \%$ linear acrylamide gels, using Laemmli's method. ${ }^{12}$ Human plasma Fn (Sigma or Boehringer Mannheim) was mixed with an equal volume of sample buffer $(0.0625 \mathrm{~mol} / \mathrm{l}$ Tris- $\mathrm{HCl} \mathrm{pH}$ $6.8,2 \%$ SDS, 5\% 2-mercaptoethanol, $10 \%$ sucrose and $0.002 \%$ bromophenol blue) and the mixture boiled for five minutes. Protein was loaded on the gels at $5 \mu \mathrm{g}$ per track. Electrophoresis was performed at $25 \mathrm{~mA}$ for two hours and the gels were then either used for Western blots or stained with Coomassie Brilliant Blue in water:methanol:acetate
(5:5:2) and destained with water: methanol:acetate (5:3:2). High molecular weight markers $(200,116,97$, and $66 \cdot 2 \mathrm{kDa})$ were used (BioRad).

Native polyacrylamide gels $(7 \cdot 5 \%)$ were prepared and run under conditions similar to those with the SDS-PAGE, but with the omission of SDS. The sample buffer contained Tris- $\mathrm{HCl}$, sucrose and bromophenol blue without either SDS or 2-mercaptoethanol.

WESTERN BLOTTING

After PAGE, the proteins were transferred to nitrocellulose membranes (Schleicher \&

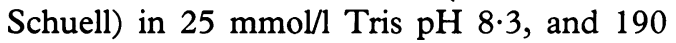
$\mathrm{mmol} / \mathrm{l}$ glycine in a BioRad Transblot system. Transfer was performed at $120 \mathrm{~mA}$ for 18 hours at room temperature. The membranes were blocked with $5 \%$ bovine serum albumin (BSA) in phosphate buffered saline containing $0 \cdot 1 \%$ Tween 20 (PBS-T) for one hour. All incubation steps were carried out at room temperature with gentle agitation. Strips of the membrane were incubated for 18 hours with rabbit anti-human Fn antiserum (The Binding Site) diluted 1:100, mouse anti-human Fn monoclonal antibody (Sigma) diluted 1:100, or a representative human serum known to contain anti-Fn antibodies ${ }^{2}$ diluted 1:50. All sera were diluted in 5\% BSA in PBS-T. The strips were then washed for 30 minutes with PBS-T, followed by a four hour incubation with horseradish peroxidase labelled goat antirabbit IgG (BioRad), goat anti-mouse IgG (Sigma) or goat anti-human immunoglobulin $\gamma$ and $\mu$ chain specific (Sigma). The strips were washed as above and bound antibodies were detected using the substrate chromogen 4-chloro-1-naphthol (Sigma).

ASSAY FOR ANTI-FN ANTIBODIES

A capture ELISA was used for quantitative determination of anti-Fn antibody concentrations. Mouse monoclonal anti-human Fn antibody was used to capture Fn from the commercial preparation. The mouse antihuman Fn monoclonal antibody was added to carbonate-bicarbonate buffer $(\mathrm{pH} \mathrm{9.6)}$, to a final dilution of $1: 2000$ and $50 \mu l$ aliquots were incubated on wells of microtitre plates (Maxisorp, Nunc) for five hours. All incubations were carried out at room temperature. The wells were then washed three times with $120 \mu \mathrm{l}$ of PBS-T. Residual binding sites were blocked with $75 \mu \mathrm{l}$ of $2 \%$ BSA for two hours. After aspiration of the BSA solution, $50 \mu \mathrm{l}$ of the Fn (Sigma) in PBS-T $(5 \mu \mathrm{g} / \mathrm{ml})$ was added to each well and the plates were incubated for 18 hours. The wells were washed again and 50 $\mu l$ of human sera diluted 1:20 in PBS-T was added to duplicate wells. The plates were incubated for two hours. After three washes, 50 $\mu l$ of alkaline phosphatase labelled goat antihuman immunoglobulin $\alpha, \gamma$ and $\mu$ chain specific (Sigma) were added to all wells and the plates incubated for one hour at room temperature. The wells were washed again and the bound reactant detected by incubation 
with $50 \mu \mathrm{l} /$ well of $1 \mathrm{mg} / \mathrm{ml}$-nitrophenyl phosphate disodium (Sigma) in diethanolamine buffer $\mathrm{pH} 9 \cdot 6$. The optical density (OD) of the colour developed was measured after 30 minutes using a Dynatech MR500 ELISA reader.

The following controls were included with each assay:

(1) Control for non-specific binding (wells blocked with BSA without prior coating with the monoclonal anti-Fn or Fn to which the sera were added in duplicate). The OD of nonspecific binding for each sample was subtracted from the OD of sample binding to Fn coated wells, and the absolute values were used to calculate anti-Fn concentrations.

(2) Positive human serum control (serum containing anti-Fn).

(3) Negative human serum control (serum lacking anti-Fn).

Six standards were used in each plate for quantitative determination of anti-Fn antibody concentrations in patients' sera. These standards were prepared from serial dilutions of anti-Fn antibodies containing serum from SLE patients. The OD obtained by ELISA at the dilutions $1: 40,1: 80,1: 160,1: 320,1: 640$, and 1:1280 were arbitrarily considered to correspond to $400,200,100,50,25$, and 12.5 $\mathrm{u} / \mathrm{ml}$ of antibodies, respectively. The programme MicroFIT version 4.7 of Microplate Software (Microtech Laborsystem) connected to the ELISA reader was used to plot the standard curves and to calculate antiFn concentrations in serum samples according to their OD values obtained by ELISA. The mean of the correlation coefficients for the six standards in 13 assays was 0.96 (SD 0.02). Sample with anti-Fn concentrations greater than $400 \mathrm{u} / \mathrm{ml}$ were further diluted, retested and the results multiplied by the dilution factors used.

\section{LABORATORY MEASUREMENT OF DISEASE}

RELATED PARAMETERS

Serum soluble interleukin-2 receptors (sIL$2 \mathrm{R})$ were measured with a commercial sandwich ELISA (Cellfree), and the results expressed as $\mathrm{u} / \mathrm{ml}$ according to the standards provided in the kit. Serum anti-dsDNA antibodies were determined using an ELISA method (Diamedic Corporation) and the results expressed in units according to the standards supplied. Urine concentrations of neopterin were determined by reverse phase high performance liquid chromatography and neopterin was expressed as $\mu \mathrm{mol} / \mathrm{mol}$ creatinine. ${ }^{13}$

Other laboratory determination were performed by standard methods: erythrocyte sedimentation rate (ESR) by the Seditainer ESR system, plasma C3 and C4 by nephelometry, plasma C3 degradation products (C3dg) by a double decker immunodiffusion method, polyclonal immunoglobulins (IgG, $\operatorname{IgM}$ and $\operatorname{IgA}$ ) by nephelometry, antinuclear antibody (ANA) titre by immunofluorescence staining and antibodies to Ro and La antigens by counterimmune electrophoresis.

\section{STATISTICAL ANALYSIS}

Results are expressed as median and interquartile range (25th-75th percentiles). MannWhitney $U$ and $\chi^{2}$ test were used for continuous and discrete variables, respectively, to test the difference between two groups. When there were more than two subgroups the Kruskall-Wallis $\mathrm{H}$ test was used. Spearman correlation was used to test the relationship between various study parameters and multiple linear regression was used to identify correlations with more than one variable. Differences between parameters within a group were evaluated with the Wilcoxon matched

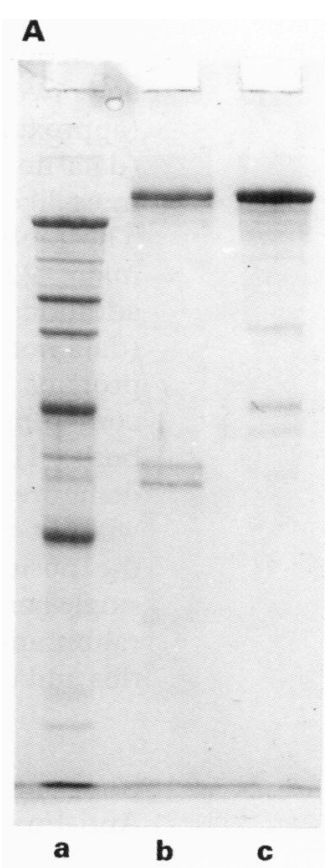

B

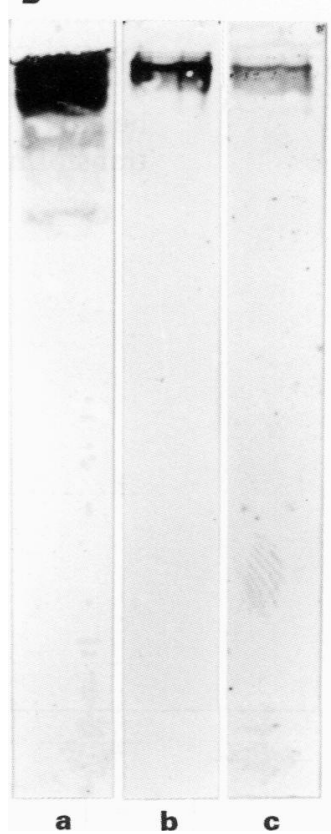

Figure 1 A: Coomassie Brilliant Blue staining of 7.5\% SDS-polyacrylamide gel. $a=$ High molecular weight marker; $b=$ Fn (Sigma); $c=$ Fn (Boehringer Mannheim). $B$ : Western Blots of $F$ n, electroblotted from a native $7.5 \%$ polyacrylamide gel and probed with rabbit polyclonal antihuman Fn (a), mouse monoclonal anti-human Fn (b) or SLE serum containing anti-Fn antibodies ( $c$ ). 
pairs signed sum ranks test. $p<0.05$ was considered significant.

\section{Results}

PURITY OF FIBRONECTIN

Purity of the manufacturers' purified human plasma Fn was tested by SDS-PAGE. Coomassie Brilliant Blue staining of the gels showed multiple protein bands in addition to the main $220 \mathrm{kDa}$ Fn band (fig 1A). To identify the additional bands, Western blotting SDS-PAGE was performed using the mouse anti-human Fn monoclonal antibody, rabbit anti-human Fn antibodies, and serum from SLE patients known to contain anti-Fn antibodies. The monoclonal anti-Fn antibody reacted weakly with the main $220 \mathrm{kDa}$ protein and two additional high molecular weight (approximately 180 and $200 \mathrm{kDa}$ ) proteins (data not shown). The latter two proteins are most likely to be breakdown products of Fn. The rabbit serum, however, reacted with the main $220 \mathrm{kDa}$ band and a number of additional proteins at lower molecular weights (data not shown). It is not clear if these smaller proteins are breakdown products of Fn, contaminating proteins, or a combination of both. Human serum failed to react with denatured Fn. Using native conditions (PAGE without SDS), the monoclonal antibody and the positive human serum produced a clear single band in the region of $220 \mathrm{kDa}$, whilst the rabbit anti-human Fn continued to react with this and other bands (fig 1B).

OCCURRENCE OF ANTI-FN IN RELATED DISEASES Anti-Fn antibody titres were not normally distributed in the healthy controls group, therefore the cut off value for a positive test was calculated after log transformation of the normal control values as suggested by Cohen et al. ${ }^{14}$ The mean $+3 S \mathrm{SD}$ of the log data for the healthy control group was then back transformed to the original scale and used as

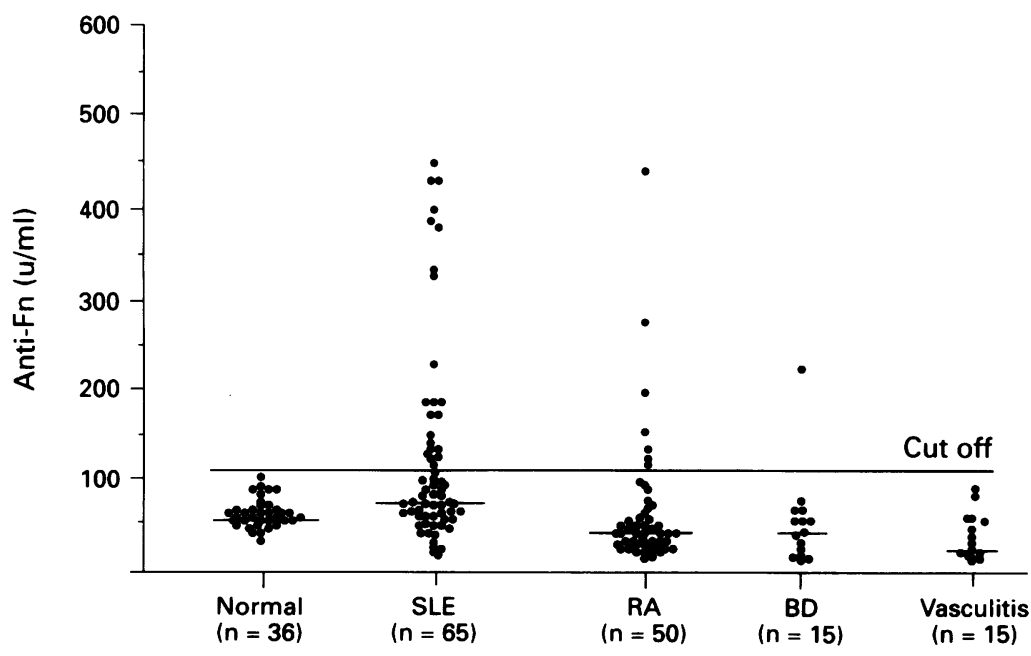

Figure 2 Anti-Fn antibody concentrations in sera from patients with systemic lupus erythematosus (SLE), rheumatoid arthritis ( $R A$ ), Behcet's disease (BD), vasculitis, and healthy controls (Normal). The continuous horizontal line represents the cut off value (mean $+3 S D$ of the log healthy control values which was back transformed to the normal scale); short lines represent median value of each group. the cut off value. Figure 2 shows that 22 of 65 patients with SLE (33.8\%), seven of 50 with RA (14\%) and one of 15 subjects with Behçet's disease $(6 \cdot 6 \%)$ had anti-Fn. The SLE group had significantly greater anti-Fn antibody concentrations (median 80, interquartile range $108 \cdot 2-324 \cdot 8 \mathrm{u} / \mathrm{ml}$ ) compared with healthy controls (median 56, interquartile range $16 \cdot 8-50 \cdot 2 \mathrm{u} / \mathrm{ml})(\mathrm{p}<0 \cdot 0001)$.

\section{ASSOCIATION OF ANTI-FN ANTIBODIES WITH} IMMUNOGLOBULIN CONCENTRATIONS AND AUTOANTIBODIES

To determine if the production of anti-Fn antibodies was part of a generalised increased production of antibodies in SLE patients, serum immunoglobulins (IgG, $\operatorname{IgM}$, and $\operatorname{IgA}$ ) were measured in 35 patients with SLE. There was no relationship between the concentrations of immunoglobulin and those of antiFn (Spearman correlation test, $r_{s}=-0.012$, $p=0.935 ; r_{s}=-0.12, p=0.489$, and $r_{s}=0.07$, $\mathrm{p}=0.715$, for $\operatorname{IgG}, \operatorname{Ig} M$, and $\operatorname{IgA}$, respectively). No significant relation was found between ANA titres of IgG or IgM class and anti-Fn activity in these 35 SLE patients (Spearman correlation tests $r_{s}=0.05, p=0.76$ and $r_{s}=-0.23, p=0.19$ for IgG and IgM ANA, respectively).

Anti-Fn antibody concentrations in SLE patients with or without antibodies to Ro or La antigens were also studied. Antibodies to the former antigen were detected in 17 of 65 patients with SLE and antibodies to the latter were present in 20 of the 65 . Concentrations of anti-Fn antibodies in the SLE group with Ro antibodies (median 81, interquartile range $100.5-301.5 \mathrm{u} / \mathrm{ml}$ ) were not significantly different $(p=0.7)$ from those without the Ro antibodies (median 72, interquartile range $104 \cdot 5-314 \cdot 2 \mathrm{u} / \mathrm{ml})$. No significant difference $(p=0.6)$ was observed between anti-Fn antibody concentrations in SLE patients with anti-La antibodies (median 43.6 , interquartile range $100.5-301.5 \mathrm{u} / \mathrm{ml}$ ) and those without anti-La antibodies (median 76.5 , interquartile range $104 \cdot 7-314 \cdot 2 \mathrm{u} / \mathrm{ml})$.

ASSOCIATION OF ANTI-FN ANTIBODIES WITH SLE TREATMENT

Fourteen SLE patients were receiving cytotoxic drugs, 21 were taking prednisolone, 14 were receiving both, and 16 were receiving hydroxychloroquine or no treatment. The median (interquartile range) anti-Fn antibody concentrations in these groups were 103 $(83 \cdot 2-249 \cdot 8) \mathrm{u} / \mathrm{ml}, 83(97 \cdot 2-291 \cdot 8) \mathrm{u} / \mathrm{ml}$, and $84(100-400) \mathrm{u} / \mathrm{ml}$, respectively. No significant differences in anti-Fn antibody concentrations were found between these groups using the Kruskall-Wallis $\mathrm{H}$ test $(\mathrm{p}=0 \cdot 28)$.

ANTI-FN ANTIBODIES IN SLE PATIENTS WITH ACTIVE OR INACTIVE DISEASE

According to the BILAG scores, 30 serum samples were from patients with active disease and 35 from patients with inactive disease. The 


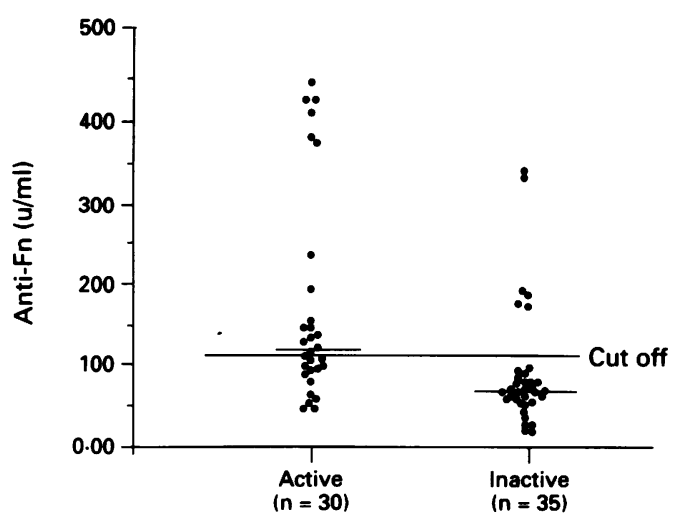

Figure 3 Anti-Fn antibody concentration (u/ml) in active and inactive SLE. The continuous horizontal line represents the cut off value (mean $+3 S D$ of the log healthy control values which was back transformed to the normal scale); short lines represent median value of each group.

two groups were not significantly different with respect to age, disease duration, and the number of ARA criteria fulfilled. Anti-Fn antibodies were found in 16 of $30(53.3 \%)$ patients with active disease and in six of 35 $(17 \cdot 1 \%)$ patients with inactive SLE (fig 3) $(p=0.005)$. Anti-Fn antibodies concentrations in the active group (median $117 \mathrm{u} / \mathrm{ml}$, interquartile range $100 \cdot 8-302 \cdot 2)$ were significantly greater $(p<0.0001)$ than in the inactive group (median $68 \mathrm{u} / \mathrm{ml}$, interquartile range $81 \cdot 7-245 \cdot 2)$.

A significant correlation was found between BILAG disease activity score and anti-Fn antibody concentrations $\left(r_{s}=0.292, p=0.018\right)$, and significant correlations were found between the amount of anti-Fn antibody and sIL-2R $\left(r_{s}=0.28, p=0.024\right), E S R\left(r_{s}=0.25\right.$, $\mathrm{p}=0.045)$, and urine concentrations of neopterin $\left(r_{s}=0.3, p=0.016\right)$ (fig 4). There were no significant correlations with plasma $\mathrm{C} 3\left(\mathrm{r}_{\mathrm{s}}=-\right.$ $0 \cdot 15, \mathrm{p}=0 \cdot 24), \mathrm{C} 4\left(\mathrm{r}_{\mathrm{s}}=-0 \cdot 15, \mathrm{p}=0 \cdot 24\right), \mathrm{C} 3 \mathrm{dg}$ $\left(r_{s}=0 \cdot 15, p=0.22\right)$, or serum antibodies to dsDNA $\left(r_{s}=0.24, p=0.051\right)$. When multiple linear regression analysis was performed using anti-Fn antibodies as the dependent variable, low significant correlations were noted with sIL-2R and BILAG disease activity score $(p=0.042$ and 0.047 , respectively).

An attempt was also made to follow anti-Fn antibody concentrations in seven SLE patients when their BILAG disease activity index changed, during two consecutive assessments, from active to inactive or vice versa. Figure 5 shows greater antibodies concentrations in the active (median $380 \mathrm{u} / \mathrm{ml}$, interquartile range 192.2-578.8) than in the inactive (median 155 $\mathrm{u} / \mathrm{ml}$, interquartile range $87 \cdot 2-261 \cdot 8)$ states $(\mathrm{p}<0.01$, Wilcoxon matched pairs signed sum ranks test).

CLINICAL AND LABORATORY FEATURES OF SLE PATIENTS WITH AND WITHOUT ANTI-FN ANTIBODIES

Of the 30 patients with active organ system involvement (table 1), 16 had increased antiFn concentrations and 14 had normal anti-Fn values. The two groups were matched for age, sex, and disease duration. Anti-Fn concentrations for 10 patients with activity in multiple organ systems (median $145 \mathrm{u} / \mathrm{ml}$, interquartile
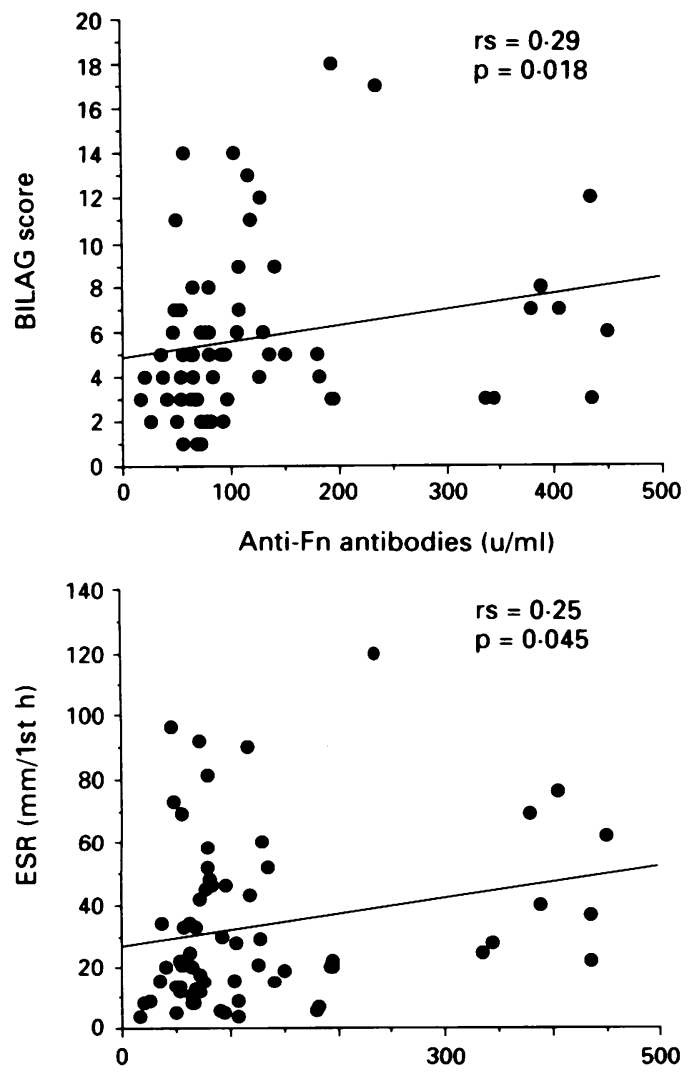

Anti-Fn antibodies (u/ml)
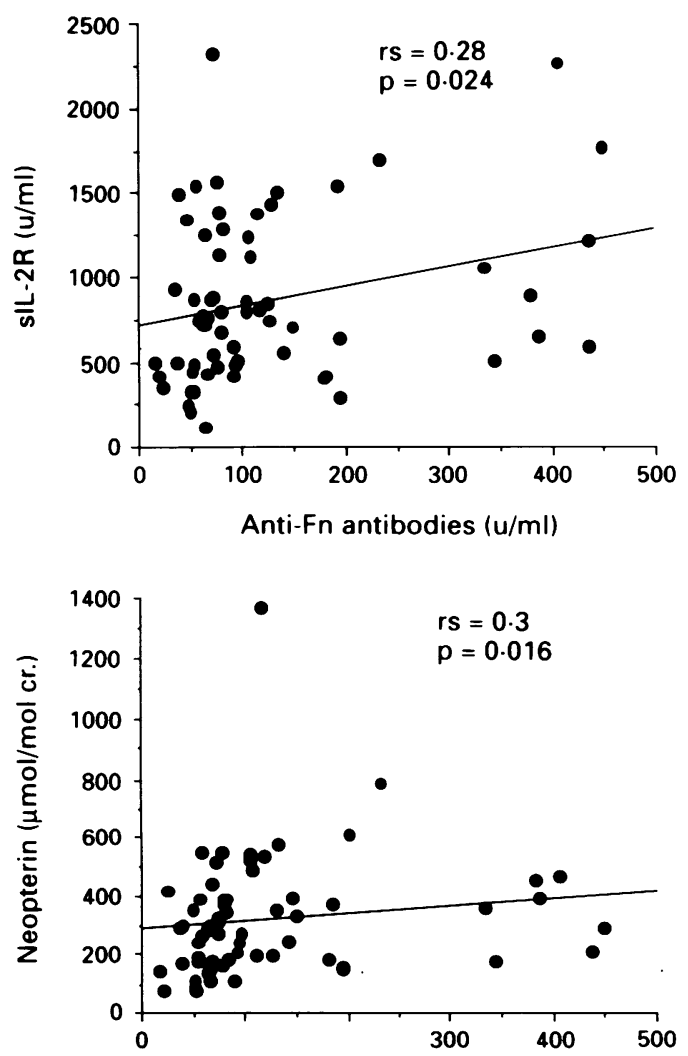

Anti-Fn antibodies (u/ml)

Figure 4 Correlation of anti-Fn antibody concentrations with BILAG score of disease activity, erythrocyte sedimentation rate $(E S R)$, and concentrations of soluble interleukin -2 receptor $($ sIL-2R) and urine neopterin. cr $=$ Creatinine. 


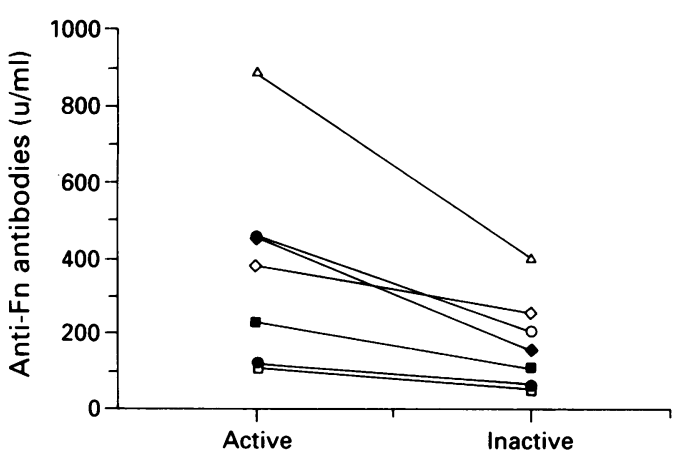

Figure 5 Individual anti-Fn antibody concentrations in seven SLE patients who suffered from flares of their disease in one of two successive assessments. The difference between anti-Fn antibody concentrations during the active compared with the inactive disease in those patients was significant ( $p>0.01$, Wilcoxon signed rank sum test).

range $89 \cdot 8-269 \cdot 2$ ) were not significantly different from those in 20 patients with single system involvement (median $106 \mathrm{u} / \mathrm{ml}$, interquartile range $108 \cdot 2-324 \cdot 2)(p=0 \cdot 19)$.

Eight of the 11 patients with active musculoskeletal system involvement (arthritis, myositis, tendonitis, arthralgia, and myalgia) had increased anti-Fn antibodies. Five of these eight patients had other organ systems actively involved: three had haematological abnormalities (anaemia, leucopenia, lymphopenia and thrombocytopenia), one had cutaneous manifestation (alopecia) and cutaneous vasculitis, and one had active renal disease. Table 1 shows that anti-Fn antibodies were increased in the three patients with active renal involvement and none of the three with active nervous system disease.

Laboratory parameters in 22 SLE patients with increased anti-Fn antibody concen- trations and 43 patients with normal anti-Fn antibody concentrations (groups comparable for age, disease duration, and ARA criteria fulfilled) were significantly different, with exception of plasma C4 and C3dg concentrations (table 2).

\section{Discussion}

The reported prevalence of increased serum antibodies to Fn in SLE patients has varied greatly (28.7-78\%) and appears to be dependent both on the technique and the species of Fn used. ${ }^{2}{ }^{3}$ The purity of Fn used in the assays may also be relevant, as binding to impurities or contaminants in Fn preparations could result in false positive results. In this study we found on Coomassie Brilliant Blue staining that human Fn preparations from two different sources (Sigma and Boehringer Mannheim) contained additional proteins. In an attempt to identify these additional bands, we used Western blotting. A number of faint reactions were obtained (in addition to the main Fn band) with a rabbit polyclonal antiserum and a mouse monoclonal anti-Fn, after SDS-PAGE. As the denaturing conditions of SDS-PAGE can affect the antigenic structure of proteins, Fn was further examined under non-denaturing (native) conditions. The mouse anti-human monoclonal antibody and a representative serum from an SLE patient known to contain anti-Fn antibodies reacted only with the main Fn band in blots from native gels, confirming specificity. The additional bands may have been breakdown products of Fn and consequently, to avoid false positive results incurred by direct coating of Fn including breakdown products onto ELISA

Table 1 Active organ system involvements according to BILAG index in SLE patients with or without anti-Fn antibodies

\begin{tabular}{lllllllll}
\hline Patients & BILAG index & & & & \\
\cline { 2 - 6 } & General & $\begin{array}{l}\text { Muco- } \\
\text { cutaneous }\end{array}$ & $\begin{array}{l}\text { Nervous } \\
\text { system }\end{array}$ & Renal & $\begin{array}{l}\text { Musculo- } \\
\text { skeletal }\end{array}$ & $\begin{array}{l}\text { Cardio- } \\
\text { vascular/ } \\
\text { respiratory }\end{array}$ & Vasculitis & Haematological \\
\hline
\end{tabular}

\begin{tabular}{|c|c|c|c|c|c|c|c|c|}
\hline \multicolumn{9}{|c|}{ With anti-Fn antibodies } \\
\hline 1 & C & $\mathbf{A}$ & $\mathrm{D}$ & $\mathrm{E}$ & C & $\mathbf{B}$ & B & $\mathbf{E}$ \\
\hline 2 & $\mathrm{C}$ & C & $\mathrm{D}$ & D & C & E & E & B \\
\hline 3 & $\mathrm{C}$ & $\mathrm{C}$ & $\mathbf{E}$ & C & $\mathbf{B}$ & D & $\mathrm{C}$ & $\mathbf{E}$ \\
\hline 4 & $\mathrm{C}$ & $\mathrm{C}$ & $\overline{\mathrm{E}}$ & $\mathrm{E}$ & $\mathbf{B}$ & $\mathrm{D}$ & $\mathrm{C}$ & $\mathbf{B}$ \\
\hline 5 & $\mathrm{C}$ & D & $\mathbf{E}$ & $\bar{E}$ & $\overline{\mathbf{A}}$ & $\bar{E}$ & $\mathrm{C}$ & $\bar{C}$ \\
\hline 6 & $\mathrm{C}$ & $\mathbf{B}$ & $\bar{E}$ & $\bar{E}$ & $\mathrm{C}$ & $\bar{D}$ & $\mathrm{C}$ & $\mathbf{B}$ \\
\hline 7 & $\mathrm{C}$ & $\mathbf{E}$ & $\mathbf{E}$ & $\mathbf{E}$ & $\mathrm{C}$ & $\bar{E}$ & $\mathbf{B}$ & $\bar{C}$ \\
\hline 8 & $\mathrm{C}$ & $\mathrm{D}$ & $\mathbf{E}$ & $\mathbf{B}$ & $\mathrm{D}$ & $\mathrm{C}$ & $\mathrm{C}$ & C \\
\hline 9 & $\mathbf{A}$ & $\mathrm{C}$ & E & $\mathrm{E}$ & $\mathrm{C}$ & $\mathbf{E}$ & $\mathrm{C}$ & $\mathrm{C}$ \\
\hline 10 & $\mathbf{A}$ & C & $\mathrm{D}$ & $\mathrm{E}$ & $\mathbf{B}$ & $\mathrm{E}$ & $\mathrm{C}$ & $\mathbf{B}$ \\
\hline 11 & $\mathrm{C}$ & B & $\mathbf{E}$ & $\mathrm{E}$ & $\mathrm{C}$ & $\mathrm{D}$ & $\mathbf{B}$ & $\mathrm{C}$ \\
\hline 12 & E & $\mathrm{D}$ & $\mathbf{E}$ & $\mathrm{E}$ & $\mathbf{B}$ & $\mathbf{E}$ & E & C \\
\hline 13 & $\mathrm{E}$ & E & $\mathbf{E}$ & $\mathrm{E}$ & B & $\mathbf{E}$ & $\mathrm{C}$ & $\mathbf{B}$ \\
\hline 14 & $\mathrm{C}$ & $\mathbf{B}$ & $\bar{E}$ & $\mathrm{E}$ & $\mathbf{B}$ & E & B & C \\
\hline 15 & $\mathrm{D}$ & $\mathrm{C}$ & $\bar{E}$ & $\mathbf{B}$ & $\mathrm{D}$ & $\mathrm{D}$ & $\mathrm{D}$ & C \\
\hline 16 & C & D & $\overrightarrow{\mathrm{C}}$ & $\overline{\mathbf{B}}$ & $\mathbf{B}$ & $\mathrm{E}$ & C & $\mathbf{E}$ \\
\hline \multicolumn{9}{|c|}{ Without anti-Fn antibodies } \\
\hline 17 & C & $\mathbf{B}$ & $\mathrm{D}$ & $\mathbf{E}$ & C & D & D & C \\
\hline 18 & $\mathrm{C}$ & $\mathrm{D}$ & $\mathrm{E}$ & $\overline{\mathbf{E}}$ & $\mathrm{C}$ & $\mathbf{E}$ & D & B \\
\hline 19 & $\mathrm{C}$ & $\mathrm{C}$ & $\mathbf{A}$ & $\overline{\mathbf{E}}$ & $\mathrm{C}$ & $\mathbf{E}$ & $\mathrm{C}$ & D \\
\hline 20 & $\mathrm{C}$ & E & E & $\bar{D}$ & $\mathrm{C}$ & D & B & D \\
\hline 21 & $\mathrm{C}$ & $\mathbf{B}$ & $\mathrm{E}$ & $\mathbf{E}$ & $\mathrm{C}$ & $\mathrm{E}$ & $\mathrm{E}$ & $\mathrm{C}$ \\
\hline 22 & $\mathrm{C}$ & $\bar{E}$ & $\overline{\mathbf{E}}$ & $\mathbf{E}$ & $\mathbf{B}$ & D & E & B \\
\hline 23 & C & $\mathbf{B}$ & $\mathbf{E}$ & E & $\mathrm{C}$ & D & $\mathrm{D}$ & $\mathrm{C}$ \\
\hline 24 & $\mathrm{C}$ & $\bar{D}$ & $\overline{\mathbf{E}}$ & $\overline{\mathrm{E}}$ & C & D & D & B \\
\hline 25 & C & C & $\mathbf{A}$ & $\mathbf{E}$ & C & D & C & C \\
\hline 26 & C & $\mathbf{B}$ & $\mathbf{E}$ & $\mathbf{E}$ & C & $\mathbf{E}$ & C & C \\
\hline 27 & D & C & $\mathbf{A}$ & $\mathbf{E}$ & $\mathbf{B}$ & $\mathbf{E}$ & D & C \\
\hline 28 & C & C & $\mathbf{E}$ & $\mathbf{E}$ & C & $\mathbf{E}$ & $\mathbf{B}$ & C \\
\hline 29 & C & D & $\mathrm{C}$ & $\widetilde{\mathbf{E}}$ & $\mathbf{B}$ & $\overline{\mathbf{E}}$ & $\overline{\mathbf{E}}$ & C \\
\hline 30 & $\mathbf{B}$ & B & $\mathbf{E}$ & D & C & C & C & $\mathrm{E}$ \\
\hline
\end{tabular}

BILAG = British Isles Lupus Assessment Group Index for disease activity. Grades $\mathbf{A}$ and $\mathbf{B}$ were taken to indicate active disease. Grades: $A=$ active disease; $B=$ less active than in $A ; C=$ stable mild disease; $D=$ previously affected but currently inactive; $\mathrm{E}=$ system never involved. $^{11}$ 
Table 2 Laboratory parameters of disease activity in SLE patients with or without increased anti-Fn antibody concentrations

\begin{tabular}{lccc}
\hline $\begin{array}{l}\text { Laboratory } \\
\text { parameter }\end{array}$ & $\begin{array}{c}\text { Anti-Fn positive } \\
(n=22)\end{array}$ & $\begin{array}{c}\text { Anti-Fn negative } \\
(n=43)\end{array}$ & $p \dagger$ \\
\hline ESR $(\mathrm{mm} / 1 \mathrm{st} \mathrm{h})$ & $28 \cdot 0(29-87)$ & $20 \cdot 0(23-69)$ & 0.027 \\
Anti-dsDNA $(\mathrm{u} / \mathrm{ml})$ & $267 \cdot 0(719-2156)$ & $<112 \cdot 0(420-1260)$ & 0.0001 \\
sIL-2R $(\mathrm{u} / \mathrm{ml})$ & $825 \cdot 0(495-1486)$ & $723 \cdot 0(555-1666)$ & 0.014 \\
C3 $(\mathrm{g} / \mathrm{l})$ & $0 \cdot 72(0 \cdot 2-0 \cdot 6)$ & $0 \cdot 87(0 \cdot 2-0 \cdot 6)$ & 0.003 \\
C4 $(\mathrm{g} / \mathrm{l})$ & $0 \cdot 15(0 \cdot 09-0 \cdot 26)$ & $0 \cdot 17(0 \cdot 1-0 \cdot 3)$ & $0 \cdot 127$ \\
C3dg $(\mathrm{u} / \mathrm{ml})$ & $12 \cdot 5(6 \cdot 8-20 \cdot 2)$ & $11 \cdot 0(10-30)$ & 0.622 \\
Urine neopterin & $351 \cdot 0(305-914)$ & $275 \cdot 0(117-350)$ & $0 \cdot 024$ \\
$\quad(\mu \mathrm{mol} / \mathrm{mol}$ creatinine $)$ & & & \\
\hline
\end{tabular}

Medians and interquartile ranges (25th-75th percentiles) are shown. †Mann-Whitney U test. antibodies during active disease and if these antibodies are a predictor of disease flares.

Significant increases in known indicators of SLE disease activity such as ESR, sIL-2R, antidsDNA and urine neopterin concentration and decreased concentrations of $\mathrm{C} 3^{16-18}$ in the group of patients with increased anti-Fn antibodies may indicate a role for anti-Fn antibodies in the immunopathology of SLE. Such a possibility accords with our previous in vitro experiments which showed that anti-Fn antibodies from SLE sera can influence interactions involving the extracellular matrix and cells, ${ }^{6}$ and with our observation that patients' anti-Fn antibodies have a high affinity for Fn which is comparable to that of anti-Fn antibodies from hyperimmune animals (unpublished data). Alternatively, the presence of the anti-Fn antibodies may be a consequence of the immunological process and could be involved in the perpetuation of the disease process.

The presence of autoantibodies in active SLE has been suggested to be a consequence of polyclonal $\mathrm{B}$ cell activation, ${ }^{19}$ antigen driven $B$ cell activation ${ }^{20}{ }^{21}$ or a combination of both mechanisms. ${ }^{22}$ As the increase in anti-Fn concentrations did not correlate with immunoglobulin concentrations (IgG, $\operatorname{IgM}$ or $\operatorname{IgA}$ ) or the titre of ANA antibodies and was not associated with $\mathrm{Ro}$ or $\mathrm{La}$ autoantibodies, selective $B$ cell activation by Fn, rather than a non-specific polyclonal activation, is more likely.

SLE is clinically and serologically a heterogeneous condition. Certain antibodies have been linked to particular clinical manifestations of SLE - for example anti-dsDNA and renal disease. ${ }^{23}$ In the analysis involving matching the presence of anti-Fn antibodies with particular clinical manifestations, with the exception of the musculoskeletal system there was broadly similar disease activity in SLE patients with and without increased serum anti-Fn antibody concentrations in the eight systems assessed. Although, on clinical grounds, most patients (eight of 11) with musculoskeletal involvement had increased serum antibodies to human $F n$, it is not possible to delineate a subset of SLE patients. It is also worth noting that anti-Fn antibodies were present in all three patients with active renal disease and none of the three patients with active neurological disease. This might suggest that anti-Fn antibodies have a role in immune complex mediated mechanisms which occur in SLE. A serial assessment of a larger number of patients which included monitoring of anti-Fn concentrations would be required to ascertain such associations.

In conclusion, we have developed a capture ELISA to measure anti-Fn antibodies in human sera. The antibodies were detected in $34 \%$ of SLE patients and in a small proportion of RA patients. The concentrations of the antibody were significantly greater in the SLE patients with active disease, and were significantly correlated with ESR, sIL-2R, and urine neopterin values. Patients with anti-Fn had more active disease as indicated by were studied in seven patients and found to be greater during active disease. However, a larger number of patients with multiple assessments is required to define the significance of anti-Fn 
laboratory indices of disease activity. Most patients with active musculoskeletal manifestations were anti-Fn antibody positive.

We are grateful to Drs D Walker and C Deighton, Consultant Rheumatologists, Newcastle-upon-Tyne, for providing serum samples from patients with rheumatoid arthritis and Dr Raida Abdul-Wahab for collecting many of the SLE blood samples. We thank The Nottingham Health Authority and The Jones Charitable Trust for their financial support.

1 Weinstein A, Bordwell B, Tibbets C, Rothfeild N Antibodies to native DNA and serum complement (C3) Antibodies to native DNA and serum complement (C3) level. Application to diagnosis and classification of systemic

2 Atta M S, Powell R J, Hopkinson N D, Todd I. Human antifibronectin antibodies in systemic lupus erythematosus: occurrence and antigenic specificity. Clin Exp Immunol 1994; 96: 20-5.

3 Henane T, Rigal D, Monier J. Anti-fibronectin autoantibodies in systemic lupus erythematosus rheumatoid arthritis and bacterial or viral infections. Pathol Biol 1986; 34: 165-71.

4 Stefanato C, Gorkiewicz-Detkow A, Jarzabek-Chorzelska M. Morphoea with high titre of fibronectin antibodies. Int 7 Dermatol 1992; 31: 190-2.

5 Rosaliti E. Fibronectin and its receptors. Ann Rev Biochem 1988; 57: 375-413.

6 Atta M S, Powell R J, Todd I. The influence of antifibronectin antibodies on interactions involving extracellular matrix components and cells. Clin Exp Immunol 1994; 96: 26-30.

7 Murphy-Ulrich G, Oberly T D, Mosher M. Serologic and pathologic studies of mice immunised with homologous fibronectin. Am F Path 1986; 125: 182-90.

8 Murphy-Ulrich G, Oberly T D, Mosher M. Detection of autoantibodies and glomerular injury in rabbits immunised with denatured human fibronectin monomer. Am F Path 1984; 117: 1-11.

9 Zanetti M, Takami T. Mesangeal deposits in rats induced by antibodies to fibronectin. Clin Immunol Immunopathol 1984; 31: 535-63.

10 Tan E M, Cohn A S, Fries J F, et al. The 1982 revised criteria for the classification of systemic lupus erythematosus. Arthritis Rheum 1982; 25: 1271-7.
11 Hay E, Bacon P, Gordon C, et al. The BILAG index: a reliable and valid instrument for measuring clinical disease activity in systemic lupus erythematosus. $O \mathcal{F M e d}$ 1993; 86: 447-58.

12 Laemmli U. Cleavage of structural proteins during assembly of the head of bacteriophage T4. Nature 1970; 227: $680-5$.

13 Slazyk W, Splerto F. Liquid chromatographic measurement of biopterin and neopterin in serum and urine. Clin Chem 1990; 36: 1364-8.

14 Cohen D E, Kaufman L D, Varma A A, Seibold J R, Steiller M, Gruber B L. Anti-laminin antibodies in collagen vascular disease: the use of adequate controls in studies of autoimmune responses to laminin. Ann Rheum Dis 1994; 53: 191-3.

15 Sato $T$, Hayashi $M$. Origin of species specificity of fibronectin. Immunological identification of speciesspecific domain of human fibronectin. 7 Biochem 1986; 99: $653-61$.

16 Swaak A, Arden L, Statius E v, Feltkamp T. Anti-ds DNA and complement profiles as a prognostic guide in systemic lupus erythematosus. Arthritis Rheum 1979; 22: 226-35.

17 Lim K L, Jones A, Brown N, Powell R J. Urine neopterin as parameter of disease activity in systemic lupus erythematosus: comparison with sIL-2R and antibodies to dsDNA, erythrocyte sedimentation rate and plasma C3, C4 and C3 degradation product. Ann Rheum Dis 1993; 52: 426-35.

18 Ter Borg E, Horst G, Limburg P, Kallenberg C. Changes in plasma levels of soluble interleukin-2 receptor in relation to disease exacerbation and levels of anti-dsDNA and complement in systemic lupus erythematosus. Clin axp Immunol 1990; 82: 21-6.

19 Sakane T, Suzuki N, Takada S, et al. B cell hyperactivity and its relation to distinct clinical features and the degree of disease activity in patients with systemic lupus erythematosus. Arthritis Rheum 1985; 31: 80-7.

20 Hardin J. The lupus autoantigens and the pathogenesis of SLE. Arthritis Rheum 1986; 29: 457-60.

21 Gharavi A, Chu J-L, Elkon K. Autoantibodies to intracellular proteins in human systemic lupus erythematosus are not due to random polyclonal B cell activation. Arthritis Rheum 1988; 31: 1337-45.

22 Dziarski R. Autoimmunity: polyclonal activation or antigen induction? Immunology Today 1988; 9: 340-2.

23 Davis P, Persy J, Russel A. Correlation between levels of DNA antibodies and clinical disease activity in SLE: retrospective evaluation. Ann Rheum Dis 1977; 36: retrospecti 